\title{
尿素とアクロレイン， クロトンアルデヒドとの反応
}

\section{Reaction and Polymerisation Products of}

\author{
Acrolein or Crotonaldehyde with Urea
}

\author{
高岡 京* • 三原一幸** \\ TAKAOKA Kyô MiHARA Kazuyuki
}

要旨

(i) 尿素とアクロレイン，クロトンアルデヒドを $2: 1,1: 2.3,1: 1$ (モル比); $\mathrm{pH} 1$ $2,6 \sim 7,9 \sim 10$; 反応温度 $3 \sim 5^{\circ} \mathrm{C}$ で応させ, アリリジンージ尿素, ジアリロール尿素, アリ ロール尿素，2-ブテニリジンージ尿素，ジクロチロール尿素を得た。

（ii）メタノール溶媒中で尿素-アクロレイン，尿素ークロトンアルデヒド，尿素-アクロレ インークロトンアルデヒドースチレン，尿素ーアクロレインースチレン等を $\alpha, \alpha$-アゾビスイソ ブチロニトリルを触媒として重合物を得てその性状を調べた。

（iii）上記生成物つ示差熱分析を行ない，結果の相異からその反応を検討した。

\section{1. 緒言}

前報 ${ }^{1)}$ では $\mathrm{C}_{2} \sim \mathrm{C}_{7}$ 脂肪族飽和アルデヒドと尿素との 反応生成物てついて報告したが，本報では不飽和アルデ ヒドとしてアクロレイン，クロトンアルデヒドを選び尿 素との反応を行なった。

アクロレインー尿素反応生成物としては，W.Schulenburg ${ }^{2)}$ が防火塗料紊たは水溶性樹脂の添加剂々して, F. Köhler ${ }^{3)}$ は尿素-ホルマリン樹脂の添加剂に，告た T.Fisher ${ }^{4)}$ は尿素ーホルマリンーアクロンイン系学光沢 メッキ用に使用している。

クロトンアルデヒドー尿素反応生成物では野上占の尿 素-ホルマリンークロトンアルデヒド樹脂，その他 ${ }^{6)}$ がみ られるが，いずれる特許で目的が樹脂類の利用にの及も 的られ，単量体の組成や高分子物の性状てついての詳細 な報告がない。

著者らは尿素とアクロレインふなはタロトンアルデヒ ドを反応させたものが自然放置点心は㽻付计により光沢 ある塗膜を形成し，なたこれらのブチルニーテル化物を 使用したアミノアルキド樹脂は光沢のすぐれた（メラミ ン系アミノアルキド樹脂より光沢がよい）塗膜を得るこ と壱予備実験により知ったので，尿素ーアクロレイン，

昭 38.5.17 受理

* 武蔵工業大学化学教室

** (現) ソーレー化学 (株), 基碟研究所
尿素ークロトンアルデヒド反応生成物について検討し， さらに尿素-アクロレイン, 尿素ークロトンアルデヒド, 尿素ーアクロレインースチレン，尿素-アクロレインークロ

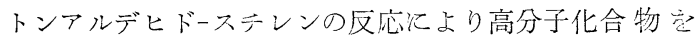
得，その性状について検討した。

\section{2. 実験および結果}

\section{$2 \cdot 1$ 試薬}

尿素は温水上り再結品苍くり返し, $\mathrm{mp} 132 \sim 3^{\circ} \mathrm{C} の$ のを使用した。

アクロレイン，クロトンデルデヒドはシリカゲルて㙂 水し, 再留をくり返して分離して来る水を除き, 無承硫 酸カルシウムにて乾燥後さらに蒸留してアクロンイン bp 50〜 $1^{\circ} \mathrm{C}$ ，クロトンアルデヒド bp 103〜 4 $4^{\circ}$ の留分を 使用した。

$\alpha, \alpha$-アゾビスイソブチロニトリル，過酸化ベンゾイ ルは市販特級品を使用した。

\section{$2 \cdot 2$ 尿素ーアクロレイン反応}

$2 \cdot 2 \cdot 1$ 室温反応

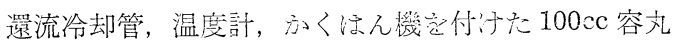
底 3 つロララス 中に $180.0 \mathrm{~g}$ (0.3 モル) の尿素を50 $\%$ 水溶液として入れ， $6 \mathrm{~N}-\mathrm{H} \mathrm{Cl}$ で $\mathrm{pH} 1$ と とてのら， 激しくかくはんしながら $8.4 \mathrm{~g}(0.15$ モル) のアクロレ インそ滴下した。温度次次第に上昇し 20 分後には $55^{\circ} \mathrm{C}$ を示し，徐々に不溶物が折出して溶剂不溶樹脂となった。 
このものは分解点 $310^{\circ} \mathrm{C}$ の淡褐色硬質樹脂で光沢を有 キるが，元素分折值にばらつきがみられ縮合，重合など 公不均一に起こっているものと考光られる。

\section{$2 \cdot 2 \cdot 2$ 低温反応}

重合，縮合反応学防ぐため反応温度を3〜 5 少量のハイドロキノンを添加して反応させた。反応装置 は室温反応の場合と同様のもの学使用した。 贸 3 $5^{\circ} \mathrm{C}$ ではアクロレインは $50 \%$ 尿素水溶液と分離 ナっので，50\%ーアクロレインーメタノール溶液として滴 下反応させた。反応開始後 $3 \sim 5^{\circ} \mathrm{C}$ で 1 時間かくはんし たの号温度を $12 \sim 20^{\circ} \mathrm{C}$ とし $4 \sim 5$ 時間反応させた。生 戎物は無色透明の粘性液体であった。

3〜 $5 \mathrm{mmHg}, 10 \sim 15^{\circ} \mathrm{C}$ にて徐々に水和よび未反応ア クロレインを徐去し, 最初に折出して来る少量の尿素の 㰴晶を口別し，乾燥を続け，半固状になったものを無水 ヌタノールに溶解してドライアイスーアセトン浴で再結 暃和よび分別結晶を行なった。反応条件扣よび生成物の 笙状を表-1〜2 に示した。

表 1 尿素ーアクロレイン反応条件执よび収率

\begin{tabular}{|c|c|c|c|c|c|c|}
\hline \multirow{2}{*}{$\begin{array}{l}\text { 泉 素-ア } \\
ク ロ レ イ \\
\text { ソ } \\
\text { (モル上) }\end{array}$} & \multirow{2}{*}{$\begin{array}{l}\text { 反応 } \\
\text { 時間 } \\
\text { (時) }\end{array}$} & \multirow{2}{*}{$\begin{array}{c}\text { 反応温度 } \\
\left({ }^{\circ} \mathrm{C}\right)\end{array}$} & \multirow{2}{*}{$\left|\begin{array}{|}\text { 反応液 } \\
\text { の } \mathrm{pH}\end{array}\right|$} & \multicolumn{3}{|c|}{ 収 率 $(\%)$} \\
\hline & & & & {$[\mathrm{I}]$} & {$[\mathrm{II}]$} & [III] \\
\hline $2: 1$ & 1 & $20 \sim 55$ & $1 \sim 2$ & \multicolumn{3}{|c|}{ 高分子物 } \\
\hline $2: 1$ & 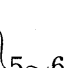 & $\int\left(\begin{array}{l}3 \sim 5 \\
(1 \text { 時間 })\end{array}\right.$ & $1 \sim 2$ & 76.0 & - & - \\
\hline $1: 2.3$ & $0 \sim 0$ & $\left\{\begin{array}{c}15 \sim 20 \\
(4 \sim 5 \text { 時間 })\end{array}\right.$ & $6 \sim 7$ & - & 82.2 & - \\
\hline $1: 2.3$ & 2 & $3 \sim 5$ & $9 \sim 0$ & - & 85.6 & - \\
\hline $1: 1$ & $5 \sim 6$ & $\left\{\begin{array}{c}3 \sim 5 \\
(1 \text { 時間 }) \\
15 \sim 20 \\
(4 \sim 5 \text { 時間 })\end{array}\right.$ & $6 \sim 7$ & - & 12.8 & $56 . i$ \\
\hline
\end{tabular}

表-2 尿素ーアクロレイン反応生成物の性状

\begin{tabular}{|c|c|c|c|c|c|c|}
\hline \multirow[t]{2}{*}{ 生成物 } & \multirow{2}{*}{${ }^{\text {融 }}\left({ }^{\circ} \mathrm{C}\right)^{\text {点 }}$} & \multirow[t]{2}{*}{$\mathrm{OH}$ 基: } & \multicolumn{2}{|c|}{$\begin{array}{l}\mathrm{NH}_{2}, \mathrm{NH} \\
\text { 基* }\end{array}$} & \multirow{2}{*}{ 元素分析值 } & \multirow[t]{2}{*}{ 分子量 } \\
\hline & & & (A) & (B) & & \\
\hline \multirow{3}{*}[I]{} & \multirow{3}{*}{$93 \sim 5$} & \multirow{3}{*}{-} & \multirow{3}{*}{+} & \multirow{3}{*}{+} & $\begin{array}{c}\mathrm{C}=37.14 \\
(37.97)\end{array}$ & \multirow{3}{*}{$\begin{array}{l}156 \sim 9 \\
(158.2)\end{array}$} \\
\hline & & & & & $\begin{array}{c}\mathrm{H}=6.29 \\
(6.37)\end{array}$ & \\
\hline & & & & & $\begin{array}{c}\mathrm{N}=34.98 \\
(35.43)\end{array}$ & \\
\hline \multirow{3}{*}{ III] } & \multirow{3}{*}{$\begin{array}{c}65 〜 8 \\
\text { (発ぽ 5) } \\
\text { 樹脂化 }\end{array}$} & \multirow{3}{*}{+} & \multirow{3}{*}{-} & \multirow{3}{*}{+} & $\begin{array}{c}\mathrm{C}=49.27 \\
(48.83)\end{array}$ & \multirow{3}{*}{$\begin{array}{l}170 \sim 5 \\
(172.2)\end{array}$} \\
\hline & & & & & $\begin{array}{c}\mathrm{H}=7.24 \\
(7.03)\end{array}$ & \\
\hline & & & & & $\begin{array}{c}\mathrm{N}=15.86 \\
(16.27)\end{array}$ & \\
\hline
\end{tabular}

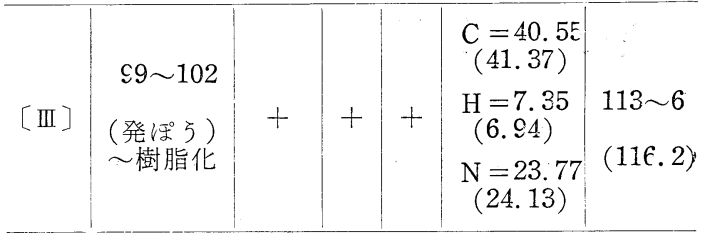

* $\mathrm{OH}$ 基ニオキシンバナジウムによる検出 ${ }^{i}$

$$
\begin{aligned}
& \text { (A) =クロルフルオレフセン共融法による } \\
& \mathrm{NH}_{2} \text { 基 } 1 \text { アミンの検出 }{ }^{8)} \\
& \mathrm{NH}^{2} \text {; 基 }(\mathrm{B})==\text { トロプルシッドナトリウム法によ } \\
& \text { る第 } 2 \text { アミンの検出 }{ }^{9)}
\end{aligned}
$$

元素分析值，分子量測定值（氷点降下法）路よび $\mathrm{OH}$ 基: ， $\mathrm{NH}_{2}, \mathrm{NH}$ 基 ${ }^{899)}$ の検出等々り[I]はアリリジン一 ジ尿素 $\left[\mathrm{H}_{2} \mathrm{NCONHCH}\left(\mathrm{CH}=\mathrm{CH}_{2}\right) \mathrm{NHCONH}_{2}\right]$ k相当す 穴。上記と同様に〔II $]$ はジリロール尿素 $\left[\mathrm{CH}_{2}=\mathrm{CH}\right.$ $\left.\left.\mathrm{CH}(\mathrm{OH}) \mathrm{NHCONH}(\mathrm{HO}) \mathrm{CHCH}=\mathrm{CH}_{2}\right], 〔 \mathrm{III}\right]$ はとアリ ロール尿素 $\left[\mathrm{CH}_{2}=\mathrm{CHCH}(\mathrm{OH}) \mathrm{NHCONH}_{2}\right]$ と考觉られこ。

酸性反応では主として $[\mathrm{I}]$ 化合物を得た。 $\mathrm{pH}$ ～10 の範囲では，尿素：アクロレイン=1:2.3 (モル比) の 反応は[II]を 83〜 5\% 得るが, 尿素 : アクロレイン= 1:1 では[III]が主生成物で〔II]も $12.8 \%$ 副生した。 [II]，[III] 化合物は加熱の際融点を示さず発ぽうして 樹脂化する。
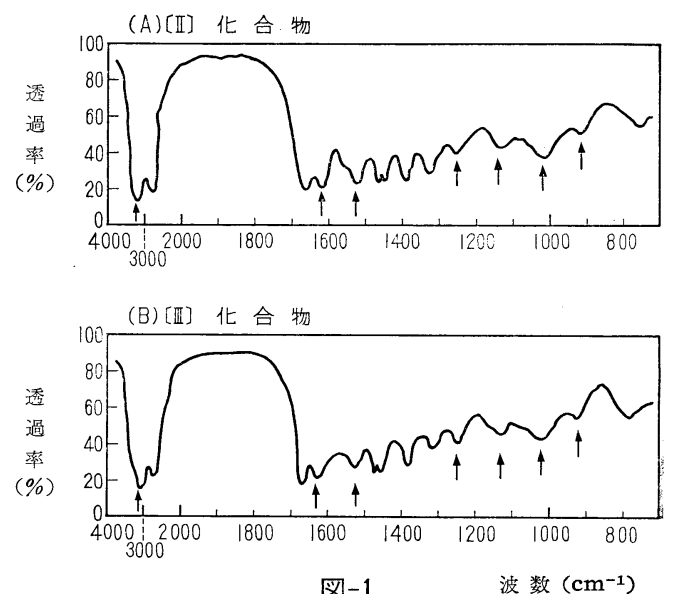

[II]，〔III]の赤外吸収スペクトルを図-1（A），（B） に示した。 $3400 \mathrm{~cm}^{-1}$ に $=\mathrm{NH}, 1640 \mathrm{~cm}^{-1}$ に $=\mathrm{CO}, 1540$ $\mathrm{cm}^{-1}$ に-CONH-, $1270 \mathrm{~cm}^{-1}$ に NH(NHCONH) の各 吸収がみられる。両者とも $1000 \mathrm{~cm}^{-1}$ 付近に幅の広い アリロール杼よび $935 \mathrm{~cm}^{-1}$ に二重結合 $\left(\mathrm{CH}_{2}=\mathrm{CH}-\right)$ の 吸収があり，二重結合拈よびアリロール基の存在を示し ている。

\section{$2 \cdot 3$ 尿素-クロトンアルデヒド反応}

$2 \cdot 3 \cdot 1$ 低温反応

反応装置和よび方法は尿素ーアクロレイン反応と同様 
に行なった。反応条件执よび生成物の性状を表-3-4 に 示した。

元素分折值, 分子量測定値, $\mathrm{OH}, \mathrm{NH}_{2}, \mathrm{NH}$ 基の検出 などさり，尿素：クロトンアルデヒド $=2: 1, \mathrm{pH} 1 \sim 2$ の反応、は $[\mathrm{N}]$ として 2-ブテニリジンージ尿素 $\left[\mathrm{H}_{2} \mathrm{~N}\right.$ $\left.\mathrm{CONHCH}\left(\mathrm{CH}=\mathrm{CH}-\mathrm{CH}_{3}\right) \mathrm{NHCONH}_{2}\right]$ を得，また尿素 : クロトンアルデヒド=1:2, pH 6〜10 では [V]化合 物ジクロチロール尿素 $\left[\mathrm{CH}_{3} \mathrm{CH}=\mathrm{CH}-\mathrm{CH}(\mathrm{OH}) \mathrm{NHCONH}\right.$ ( $\mathrm{HO}) \mathrm{CH}-\mathrm{CH}=\mathrm{CHCH}_{3}$ 〕 主生成物として得た。

[V]は 126〜 $8^{\circ} \mathrm{C}$ で発ぽうしたのち樹脂化し [II], [III〕同様にアルキロール尿素であることを示してい $\because 0$

$[\mathbb{N}],[\mathrm{V}]$ の赤外吸収スペクトルを図-2（A), (B) に示し心。[II], 〔III]と同様に $=\mathrm{NH},=\mathrm{CO},-\mathrm{CONH}-$ 等の吸収がみられるが，〔N]では $1130 \mathrm{~cm}^{-1} に-\mathrm{NH}$ $\mathrm{CH}_{2} \mathrm{NH}$ - (非対称振動) と考兄られる吸収がみられ, 京 た $880 \mathrm{~cm}^{-1}$ にメチレンジ尿素の特性吸収にほぼ一致す らものボあり，2-ブテニリジンージ尿素のアルキリジン 構造䒜しているものと考えられる。[V]では 1020 $\mathrm{cm}^{-1}$ にクロチロール基の特性吸収と考觉られる新しい 吸収がみられ， $960 \mathrm{~cm}^{-1}$ に二重結合の吸収があった。

表-3 尿素-クロトンアルデレド反応条件および収率

\begin{tabular}{|c|c|c|c|c|c|}
\hline \multirow{2}{*}{$\begin{array}{c}\text { 尿素ークロ } \\
\text { ンアルデヒド } \\
(\text { (モル比) }\end{array}$} & \multirow{2}{*}{$\begin{array}{l}\text { 反応 } \\
\text { 時間 } \\
\text { (時) }\end{array}$} & \multirow{2}{*}{$\begin{array}{c}\text { 反応温度 } \\
\left({ }^{\circ} \mathrm{C}\right)\end{array}$} & \multirow{2}{*}{$\begin{array}{l}\text { 反応液 } \\
\sigma \mathrm{pH}\end{array}$} & \multicolumn{2}{|c|}{ 収率(\%) } \\
\hline & & & & {$[\mathbb{N}]$} & {$[\mathrm{V}]$} \\
\hline $2: 1$ & & $3 \sim 5$ & $1 \sim 2$ & 87.1 & - \\
\hline $1: 2$ & $5 \sim 6$ & $\begin{array}{c}\text { (1 時間) } \\
15 \sim 20\end{array}$ & $6 \sim 7$ & - & 79.5 \\
\hline $1: 2$ & & (4〜5時間) & $9 \sim 10$ & - & 53. $2^{*}$ \\
\hline
\end{tabular}

* 粘体副生成物（精製困雑）を得た。

表-4 尿素ークロトンアルデヒド反応生成物の性状

\begin{tabular}{|c|c|c|c|c|c|c|}
\hline \multirow{2}{*}{ 生成物 } & \multirow{2}{*}{ 融 $\left({ }^{\circ} \mathrm{C}\right)^{\text {点 }}$} & \multirow{2}{*}{$\begin{array}{l}\mathrm{OH} \\
\text { 基 }\end{array}$} & \multicolumn{2}{|c|}{$\begin{array}{l}\mathrm{NH}_{2}, \mathrm{NH} \\
\text { 基 }\end{array}$} & \multirow{2}{*}{ 元素分析值 } & \multirow{2}{*}{ 分子 量 } \\
\hline & & & (A) & (B) & & \\
\hline$[N]$ & $206 \sim 9$ & - & + & + & $\begin{array}{c}\mathrm{C}=41.21 \\
(41.85) \\
\mathrm{H}=7.45 \\
(7.02) \\
\mathrm{N}=32.19 \\
(32.54)\end{array}$ & $\begin{array}{r}168 \sim 172 \\
(172.2)\end{array}$ \\
\hline$[\mathrm{V}]$ & $\begin{array}{l}126 \sim 8 \\
\text { (発汸 5 ) } \\
\text { ～樹脂化 }\end{array}$ & + & - & + & $\begin{array}{c}\mathrm{C}=53.01 \\
(53.98) \\
\mathrm{H}=7.84 \\
(8.06) \\
\mathrm{N}=13.32 \\
(13.99)\end{array}$ & $\begin{array}{l}194 \sim 8 \\
(200.2)\end{array}$ \\
\hline
\end{tabular}
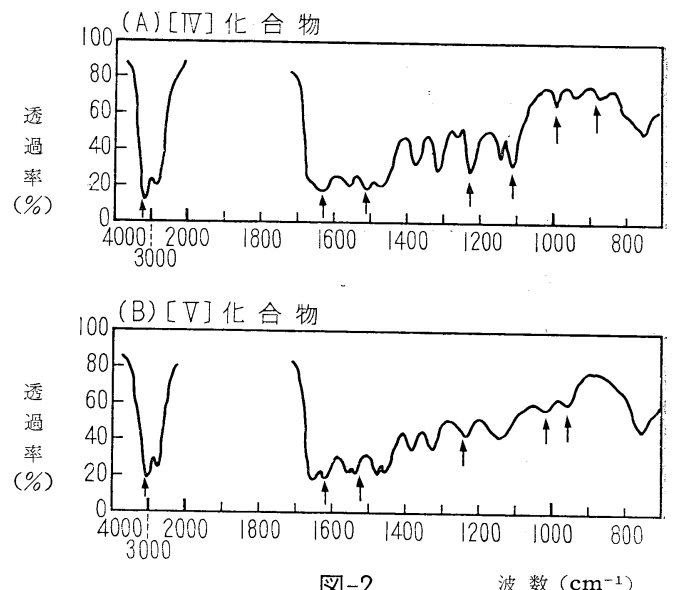

図-2

波数 $\left(\mathrm{cm}^{-1}\right)$

$2 \cdot 4$ 尿素-アクロレイン, 尿素-クロトンアルデヒド の重合反応およびスチレンとの共重合

$200 \mathrm{cc}$ 容耐圧試験管中ルアクロレイン $28.0 \mathrm{~g}$ (0.5 モ ル）と尿素 $30.0 \mathrm{~g}(0.5$ モル) を $100 \mathrm{cc}$ のメタノール に溶解して入れ， $\alpha, \alpha$-アゾビスイソブチロニトリル 2 $\mathrm{g}$ そ加光, ドライアイスーアセトン浴にて冷却固化しなが. ら十分減压として $\mathrm{N}_{2}$ ガスを置換し，この操作を 10 回 くりかえしたのち封じた。これを恒温槽中 $60 \sim 63^{\circ} \mathrm{C} て ゙$ 50 時間反応させた。反応終了後溶剂不溶生成物は減圧 乾燥し, 溶剤可溶性生成物は水洗により, 未反応尿素を 除き， $5 \sim 8 \mathrm{mmHg}, 80^{\circ} \mathrm{C}$ にて十分乾燥した。反応条件 抢よび生成物の性状を表-5に示した。

アルコール類に可溶である [UII], [X] 重合物は分子 量が 2160,2210 といずれも小さいがカルボニル価は $21.4 ， 26.0$ で大部分のアルデヒド基は尿素と反応して いることを示している。[VI] は白色硬質樹脂でメタノ ールに長時間漬けて括くと膨潤した。〔X], [XI〕とも. に溶剤不溶樹脂となった。

\section{$2 \cdot 5$ 尿素-アクロレイン, クロトンアルデヒド反応生} 成物および重合物の示差熱分析 [DTA]

測定は島津製 DT-10 形を使用し, $10^{\circ} \mathrm{C} / \mathrm{min}$ の昇温 速度で 30〜 $600^{\circ} \mathrm{C}$ 間を測定 ${ }^{10)}$ した。

$2 \cdot 5 \cdot 1$ 尿素ーアクロレイン, クロトンアルデヒド反応 生成物

$[\mathrm{II}],[\mathrm{N}],[\mathrm{V}]$ 化合物の測定を行ない，アルキロー ル尿素とアルキリジン尿素の差和よび〔II〕に対しては

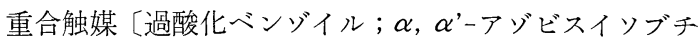
マニトリル〕を添加した時の変化等について検討した。

a) [II]化合物の DTA

[II]の DTA 曲線を図-3 (A) (B) (C) に示した。

i ） $65 \sim 8^{\circ} \mathrm{C}$ に中位の幅広い吸熱ピークがみられ, 
表-5 重合条件抏よび生成物の性状

\begin{tabular}{|c|c|c|c|c|c|c|c|c|c|}
\hline \multirow{2}{*}{ 重合物 } & $\begin{array}{l}\text { アルデ } \\
\text { ヒド稹 }\end{array}$ & 尿素 & スチ & \multirow{2}{*}{$\begin{array}{c}\text { 反 応 } \\
\text { 温 度 } \\
\left({ }^{\circ} \mathrm{C}\right)\end{array}$} & \multirow{2}{*}{$\begin{array}{c}\text { 反 応 } \\
\text { 時 間 } \\
\text { (時) }\end{array}$} & 触媒 & \multirow{2}{*}{$\begin{array}{l}\text { 生成樹脂 } \\
\text { 外 観 }\end{array}$} & \multirow{2}{*}{ 溶 } & \multirow{2}{*}{ そ } \\
\hline & \multicolumn{3}{|c|}{ （モル比） } & & & 雾囲 気 & & & \\
\hline$[\mathrm{V}]$ & Ac 1 & - & - & 85 & \multirow{3}{*}{$\begin{array}{l}24 \\
50 \\
30\end{array}$} & \multirow{3}{*}{$\begin{array}{l}\alpha, \alpha '-ア ソ ゙ \\
\text { ビスイソブ } \\
\text { チロニトリ } \\
ル\end{array}$} & \multirow{3}{*}{$\begin{array}{l}\text { 淡黄色粘体 } \\
\text { 白色 固 体 } \\
\text { 淡黄色粘体 }\end{array}$} & アルコール類 & $\begin{array}{l}\text { 分子量 }=1340 \\
\text { カルボ }=\text { ル価 }=561.3\end{array}$ \\
\hline [UI] & Ac 1 & 1 & - & \multirow{5}{*}{$60 \sim 63$} & & & & - & - \\
\hline [VIII] & Ac 2 & 1 & - & & & & & アルコール類 & $\begin{array}{l}\text { 分子量 }=2160 \\
\text { カル価 }=21.4\end{array}$ \\
\hline$[\mathbb{X}]$ & Ac 1 & 1 & 1 & & \multirow{3}{*}{50} & $\mathrm{~N}_{2}$ ガス & \multirow{3}{*}{$\begin{array}{l}\text { 黄色粘 体 } \\
\text { 白色固 体 } \\
\text { 淡黄色固体 }\end{array}$} & \multirow{3}{*}{$\begin{array}{c}\text { アルコール類 } \\
-\end{array}$} & $\begin{array}{l}\text { 分子量 }=2210 \\
\text { カルボ }=26.0\end{array}$ \\
\hline$[\mathrm{x}]$ & $\operatorname{Cr} 1$ & 1 & - & & & & & & - \\
\hline$[\mathrm{XI}]$ & $\begin{array}{l}\text { Ac } 1 \\
\text { Cr } 1\end{array}$ & 1 & 1 & & & メタノール & & & - \\
\hline
\end{tabular}

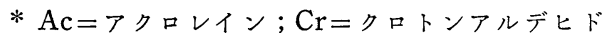

発ぽう温度とほぼ一致する。 $100^{\circ} \mathrm{C}$ ら徐々に降温させ た場合発熱ピークがみられないため, 上記吸熱ピークは 不可逆である。すなおち $\mathrm{mp}$ ではなく縮合反応による脱 水が加わっているものと考学られる。モノメチロール尿 素[図-3(F)] の $110^{\circ} \mathrm{C}$ の吸熱ピークも同様の現像を示 した。

ii) $75 \sim 115^{\circ} \mathrm{C}$ に数多くの小さい吸熱ピーク持よび 165 $200^{\circ} \mathrm{C}$ に前者よりも小さい吸熱ピークの 1 群がみ られる。これらは縮合反応に起因するのではないかと考 壳らる。

iii）【II]に過酸化ベンゾイルまたは $\alpha, \alpha$-アゾビス イソブチロニトリルを添加して DTA の測定（図-3 B, C) を行なら と前者では $95^{\circ} \mathrm{C}$ 付近, 後者では $108^{\circ} \mathrm{C}$ 付 近に大きく少し幅の広い発熱ピークを生ずる。 $\left(10^{\circ} \mathrm{C} /\right.$ $\min$ の昇温速度では過酸化ベンゾイルは $85^{\circ} \mathrm{C}, \alpha, \alpha^{\prime}-ア$ ゾビスイソブチロニトリルは $95^{\circ} \mathrm{C}$ に幅のせ案いピーク があらわれる)。DTA 測定前の[II]赤外吸収スペクト ルと上記重合触媒を添加後 $10^{\circ} \mathrm{C} / \mathrm{min}$ の昇温速度で 150 ${ }^{\circ} \mathrm{C}$ な゙加熱したものの赤外吸収スペクトルを比較すると $935 \mathrm{~cm}^{-1}$ の $-\mathrm{CH}=\mathrm{CH}_{2}$ の吸収は後者が減少している。こ のことよりこの発熱ピークは重合熱を示していらと考え られる。

iv） $380^{\circ} \mathrm{C}$ 付近に吸熱ビークがみられるが，ポリ尿 素（図-4D）に新いて $390^{\circ} \mathrm{C}$ 付近に分解と考光られる大 きい吸熱ピークがあることから，このピークは分解を示 すものと考光られ。

b) $[\mathbb{N}]$ 化合物の DTA

アルキリジン尿素であるため〔II〕異なった DTA を示した。

i) $205^{\circ} \mathrm{C}$ 付近に比較的鋭い吸熱ピークがみられ融点 を示している。
ii）【II〕にみられた $100 \sim 200^{\circ} \mathrm{C}$ 間の縮合性小吸熱 ピーク群はみられない。

iii） $410^{\circ} \mathrm{C}$ の吸熱ピークはポリ尿素の分解ピークに 類似している。

iv）完全分解ピークは $510^{\circ} \mathrm{C}$ にみられる。

C ） [V] 化合物の DTA

[II]乙類似した DTA 曲線を得た。

i) $125^{\circ} \mathrm{C}$ に発涪う温度に岕たる吸熱ピークがみられ る。

ii） $130 \sim 200^{\circ} \mathrm{C}$ 間㴼合性吸熱ピークがみられる。

iii） $405^{\circ} \mathrm{C}$ の吸熱ピークはポリ尿素の分解ピークに 類似している。

致 iv） $500^{\circ} \mathrm{C}$ 付近に完全分解ピークがみられる。

[II]，[V]のアルキロール尿素系では融点を示さずま た $100 \sim 200^{\circ} \mathrm{C}$ 間に縮合性吸熱ピーク群がタられるが, [N] のアルキリジン尿素系では融点を示し $100 \sim 200^{\circ} \mathrm{C}$ 間には汇とんど変化がみられなかった。

$2 \cdot 5 \cdot 2$ 尿素ーアクロレインークロトンアルデヒドースチ レン重縮合物の DTA

a）室温反応樹脂の DTA

溶剂不溶性樹脂の DTA を図-4（A）に示した。

i) $100 \sim 200^{\circ} \mathrm{C}$ 間には縮合性吸熱ピーク群がみられ ない。このことより縮合反応が進んでいるものと考兑ら れる。

ii） $310^{\circ} \mathrm{C}$ 付近に吸熱ピークがあり融点（なたは一部 分解）を示している。

iii) $405^{\circ} \mathrm{C}$ 付近に吸熱ピークが女りポリ尿素形分解 を示している。

iv） $550^{\circ} \mathrm{C}$ に吸熱がヌられ完全分解と考兄られる。

b ）室温重合物（自然放置）の DTA

[II〕室温に放置したものは硬化するが, 笢のものの 


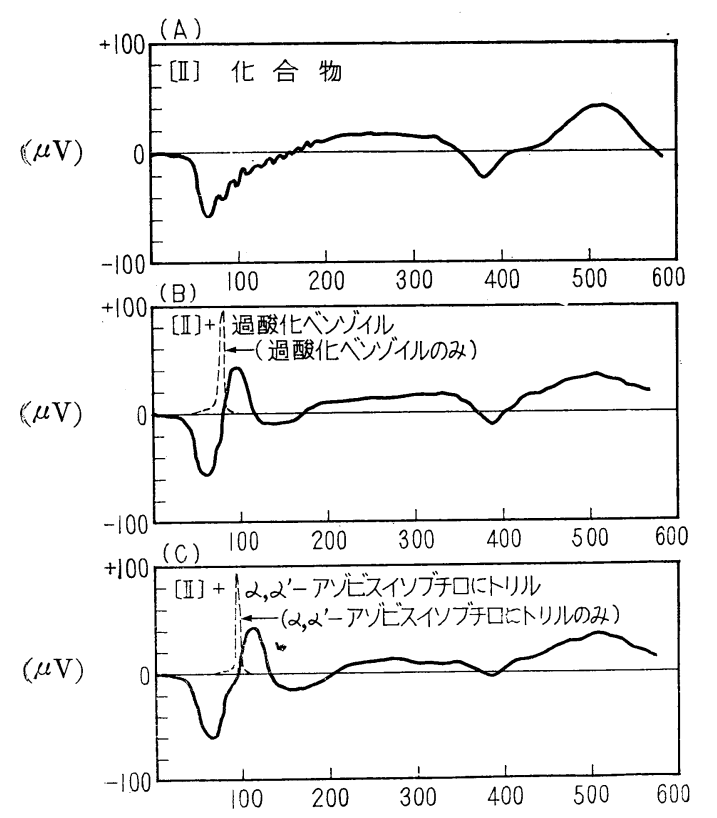

\section{えられる。}

iii） $405^{\circ} \mathrm{C}$ にはポリ尿素形分解を示している。

iv） $520^{\circ} \mathrm{C}$ に完全分解吸熱ピークがみられるが a)よ りも低温度にみられた。

c) 〔UI]樹脂の DTA

図-4（c）にこれを示した。

i） $330^{\circ} \mathrm{C}$ 飞幅広く浅い吸熱ピークがあり a)の融点 （または分解点）にがいとうする。

ii） $410^{\circ} \mathrm{C}$ に幅広く浅い吸熱ピークがありポリ尿素の 分解にがいとうする。

重縮合が進み高分子化したものの DTA ほど曲線は変 化が少なくなった。
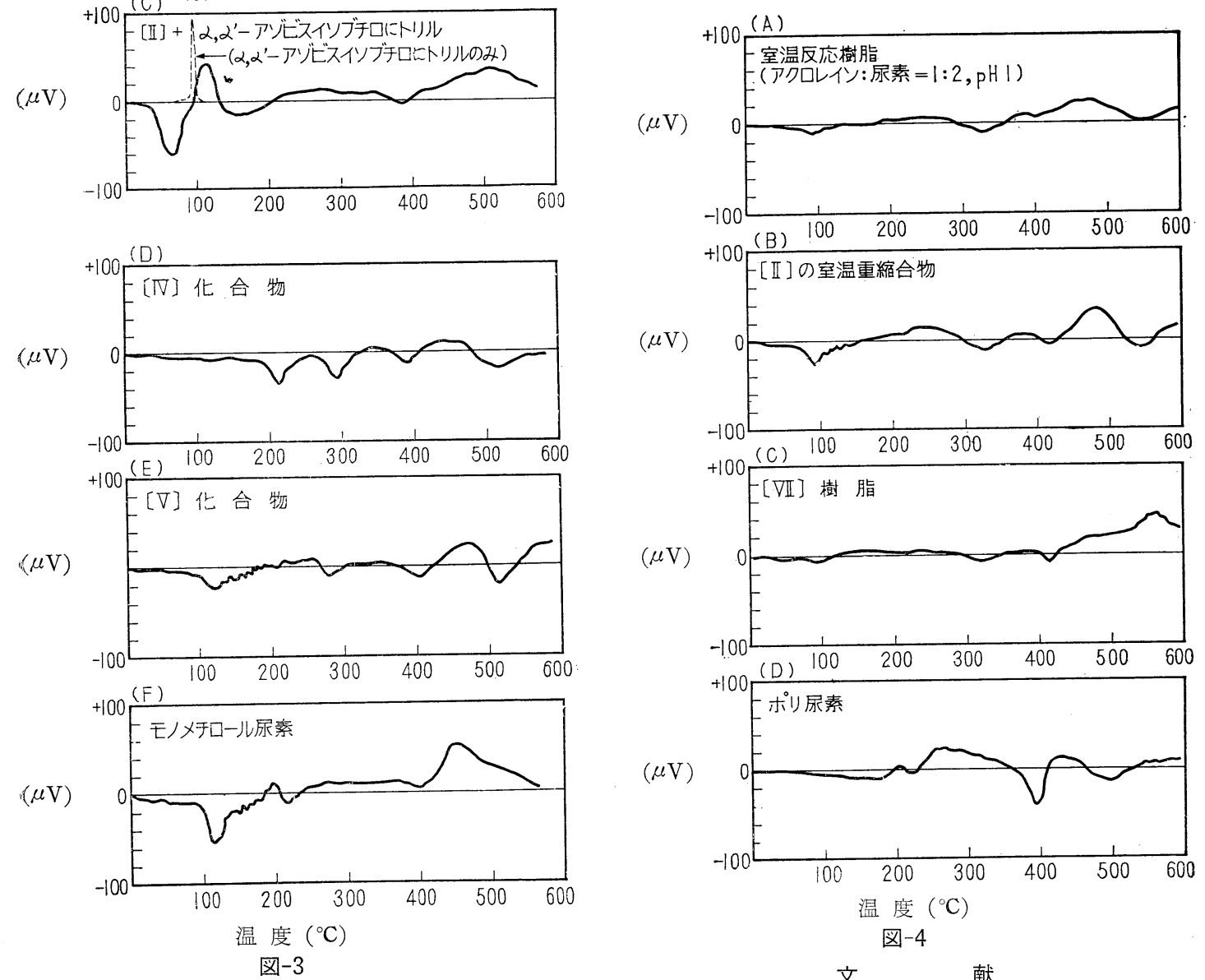

DTA 曲線を図-4（B）に示した。

i）吸熱ピークは $90^{\circ} \mathrm{C}$ にあり〔II]の場合よりも高 くなっている。115 $170^{\circ} \mathrm{C}$ 縮合性吸熱ピーク群がみ られる。

ii） $315^{\circ} \mathrm{C}$ 付近に a ) と同様な吸熱ピークがあり [II] にはみられない。高分子化していることを示すものと考

$(\mu \mathrm{V})$

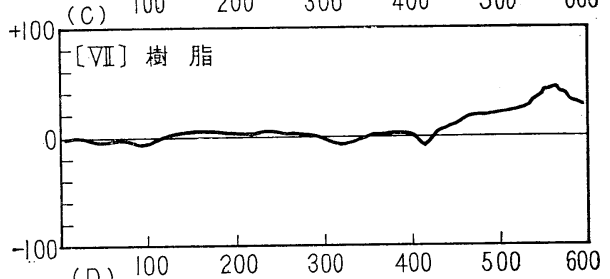

$(\mu \mathrm{V})$

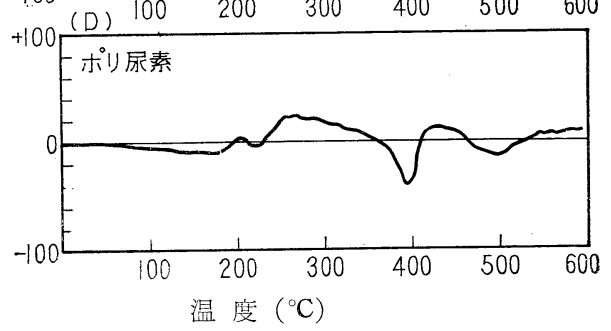

図-4

$$
\text { 文献 }
$$

1) 高岡, 長倉, 三原, 色材 36, 164 (1963)

2) W. Schulenburg, U. S. Patent 2, 881, 088(1959) ; Ger,. Patent 962,824 (1957) ; Ger. Patent 965, 766 (1958)

3) F. Köhler, Ger. Patent 875, 945 (1953), Ger. Paetnt 803, 854 (1951), Ger. Patent 802, 846 (1951) 
4) J. Fisher, Ger. Patent 924, 489 (1955)

5) 野上, 日本特, 1,237 (1958)

6) K. Ott, K. Hamann, Ger. Patent 733, 496 (1943)

7) F. Feigl, C. Stark, Mikrochim. Acta 1955 996;

D. A. Pantong, Anal.Chim. Acta, 13; 1 (1955)

8) F. Feigl, V.Auger, R.Zappert, Mikrochemie, 16, $67(1934)$
9) F. Feigl, V. Auger, Mikrochim. Acta 1, 138: (1937)

10) 山本, 分折化学, 11, 943 (1962)

(昭和 37 年 10 月 1 部を日本化学会東北地方大会並 びに昭和 37 年 11 月 1 部を色材協会関西支部秋季研究: 発表会にて講演）

\section{色 材 協 会誌 第 36 巻 第 9 号 (予告)}

文

塗料用ポリエステル樹脂に関する研究（第 7 報）

.野間夫之, 四十宮竜德（京都大学，高分子化学工業(株)） エポキシ樹脂就よびエポキシェステルの分子量分布…………高橋誠一（大日本インキ化学工業(株))

塩化ビニルプラスチゾルのゲル化塗膜の透湿率に及ぼす可塑剤括よび充テン剂配合量の効果 ·近藤泰蔵, 稲村恵三 (関西ペイント(株))

資 料

ゲル化の問題 吉田豊彦 (日本油脂(株)塗料研究所)

最近の建築塗装の問題点 近藤重之助（建設省建築研究所） 色材サロン

塗装と色彩. 副島啓治（(株)副島塗装店）

文献，特許抄録，業界ニュース 